http://dx.doi.org/10.21707/gs.v11.n02a11

\title{
Socio-ecological diagnosis on the semiarid of Paraíba: AN ANALYSIS OF ENVIRONMENTAL CULTURE AND PERCEPTION
}

\author{
Lívia Feijó Portela ${ }^{1 *}$, Gustavo Ferreira da Costa Lima², Denise Dias da Cruz ${ }^{3}$
}

\begin{abstract}
${ }^{1}$ Discente do Programa de Pós graduação em Desenvolvimento e Meio Ambiente, Universidade Federal da Paraíba
${ }^{2}$ Docente do Departamento de Ciências Sociais, Centro de Ciências Humanas, Letras e Artes, Universidade Federal da Paraíba

${ }^{3}$ Docente do Departamento de Sistemática e Ecologia, Centro de Ciências Exatas e da Natureza, Universidade Federal da Paraíba

*Autor para correspondência: liviafportela@gmail.com
\end{abstract}

Recebido em 27 de outubro de 2015. Aceito em 23 de maio de 2017. Publicado em 29 de julho de 2017.

REsumo - Mudanças culturais são um grande desafio à redução de impactos ambientais e ao ideal da convivência com o semiárido, especialmente nas zonas urbanas, onde há um distanciamento maior com relação ao ambiente do semiárido. O presente estudo teve como objetivo diagnosticar os principais problemas socioambientais do bairro Jardim Sant'ana, cidade de Sousa, semiárido da Paraíba, e avaliar a percepção da população em relação à cultura ambiental. A pesquisa tem uma abordagem qualiquantitativa, realizada com base em levantamento bibliográfico e documental, por meio de pesquisa de campo, utilizando-se de pressupostos teóricos da pesquisa fenomenológica e observação participante. Elaborou-se um diagnóstico socioambiental do referido bairro, ferramenta importante para embasar a construção de políticas públicas de convivência com o semiárido. Dentre os principais resultados obtidos, destaca-se o índice de impacto ambiental de -4,58, evidenciando uma forte pressão na área estudada.

Palavras-chave: Impactos Ambientais; Zonas Urbanas; Políticas Públicas.

Socio-environmental diagnosis in the semiarid region of Paraíba: an analysis of the perception and ENVIRONMENTAL CULTURE

Abstract - Cultural changes constitute a great challenge to the reduction of environmental impacts and to the ideal coexistence with the semiarid region, especially in urban areas, where there is a greater detachment regarding from the semiarid environment. This study aimed to diagnose the main socio-environmental problems in the neighborhood of Jardim Sant'ana, in the municipality of Sousa, in the semiarid region of Paraíba State, Brazil, and to assess the population's perception of environmental culture. This is a qualitative and quantitative study, performed based on bibliographic and documentary survey, from a field research, using theoretical assumptions from phenomenological research and participant observation. A socio-environmental diagnosis of the above mentioned neighborhood was carried out and consisted of an important tool to lay the foundation of the development of public policies on the coexistence with the semiarid region. The environmental impact index (-4.58) stood out among the main results found here, indicating a strong pressure on the studied area.

Keywords: Environmental Impacts; Urban Areas; Public Policies.

\section{DiagNósTiCo SOCIOAMBIENTAL DEL SEMIÁRIDO PARAIBANO: UN ANÁLISIS DE LA PERCEPCIÓN Y CULTURA AMBIENTAL}

RESumen - El cambio cultural es un reto importante para reducir los impactos ambientales y para el ideal de la convivencia con la región semiárida, especialmente en las zonas urbanas donde hay un mayor distanciamiento con respecto a la región semiárida. El objetivo de este estudio fue diagnosticar los principales problemas socioambientales del barrio de 
Sant'ana Jardim, en la ciudad de Sousa, región semiárida del estado de Paraíba, Brasil, y evaluar la percepción de la población respecto a la cultura ambiental. Esta investigación tiene un enfoque cuali-cuantitativo, y se realizó basada en un levantamiento bibliográfico y documental, a través de la investigación de campo, utilizando supuestos teóricos de la investigación fenomenológica y la observación participante. Se elaboró un diagnóstico socio-ambiental del referido barrio, lo que consistió en una herramienta importante para apoyar la construcción de políticas públicas de convivencia con la región semiárida. Entre los principales resultados obtenidos, se destaca el índice de impacto ambiental $(-4,58)$, lo que indica una fuerte presión sobre el área de estudio.

Palabras clave: Impactos Ambientales; Áreas Urbanas; Políticas Públicas.

\section{INTRODUCTION}

The size and water volume of Brazilian rivers and waterfalls have pervaded our culture with the idea of the inexhaustibility of natural resources. Brazil is a privileged country for having $12 \%$ of all fresh water on the planet within its territory. However, the great human clusters in our country have not settled according to water distribution; 70\% of Brazil's fresh water is in the Amazon, where only 7\% of the population lives, while the Northeast region, which is highly populated, has only 3\% of the country's fresh water (Senra et al., 2012).

The water cycle, the simplest ecological cycle, highlights its irreplaceability and its essentiality for all life on the planet. Brazil's urban areas can be understood as a consumer center of the social system, intrinsically connecting themselves to the complex ecosystems around them to meet their energy, natural resources and waste disposal needs. However, urban life does not give new organic elements back to these ecosystems so that the cycle can be closed again. This is an exploratory behavior regarding the world's natural resources, in which activities are performed in an unsustainable manner, using resources with complete disregard for the length of time it takes for them to restore themselves, producing more waste in the environment than the world's resilience capacity can cleanse. Thus, it is possible to perform an analysis of how unsustainable the current urban lifestyle is and to determine the need for significant changes in this scenario (Branco, 2004; Crispim, 2008).

However, transitioning to sustainability is hindered by a set of factors associated with educational and environmental deficits, socio-ecological conflicts between private and public agents, low political participation and the precarious nature of the institutions dedicated to environment control and management. New proposals for contemporary urban challenges usually depend on the production and effectuation of public policies in all territories and on the knowledge, perception and value that society gives to the environment, which are still the focus of social conflict and dissent.

One of the difficult factors that should be highlighted is the "Coronelismo" or "rule of the coronels", an old practice still present in Brazil's political life that can disrupt or stagnate communities (Mitidiero Junior, 2008). This arbitrary manifestation of power is based on exchanges of benefits between the public power, which grows increasingly stronger, and the private power of local bosses of decreasing influence. This practice occurred mainly between landowners of rural Brazil during the transition from the 19th to the 20th century and is currently undergoing a rereading, being named "neocoronelismo" (Carvalho, 1987; Salles, 2012; Tonet, 2014). The phenomenon is present mainly in the poorest regions of Brazil and in smaller provincial towns. The practice still survives in the Brazilian northeast region, and its mechanisms of maintaining a large section of the population under the domain of minority interests hinders the advance of democracy and the regression 
of centenary issues of the semiarid region, such as power, land concentration and survival in the context of climatic adversities (Cohn, 1995; Martins et al. 2011).

The needs of the population are between the political interests on the one side and the impasses on the other side. In the Brazilian semiarid, habitual characteristics have become subject to manipulation. One example worth mentioning is the long drought period, common in the Caatinga biome, which causes several difficulties among the population. However, the drought period allows various agents to use this reality for countless types of interests. An example of this manipulation is the incentive to subjugate the population to adopt a submissive stance, which is enforced by political agents, turning this opportunity into a voting industry (Baptista, 2013). An alternative concept of the idea of "drought relief" has been created in the semiarid. This idea is based on the understanding that the people are citizens; that it is possible and viable to coexist with this region; that social justice is built on gender equality and female leadership; and that a context-based education is key to the appreciation of traditional knowledge in coexisting with the semiarid (Baptista, 2014a).

As a primary impact, the development of public policies based on participative principles aimed at distributing the growth benefits among the population as a whole provokes citizenship awareness on those that receive them. However, the affected population needs time to consolidate it; time that usually exceeds the mandate of those ruling at the time of their implementation. Such policies are fundamental for coexistence with the semiarid. Such idea of coexistence demands a universalization of practices that have already been in place for a few decades and proved the possibility of living in socio-ecological harmony with the semiarid, despite its climatic adverse conditions. Is a matter of adaptability and of search for ways to maintain the region's environmental balance (Baptista, 2014a).

The development of public policies capable of promoting a new environmental culture in the urban population of the semiarid is of great importance for reducing socio-environmental impacts that afflict the Caatinga environment due to the lack of understanding of the population in relation to their habitat. Environmental culture can be defined as the capacity to transform values and attitudes aimed at environmental awareness, social sustainability, care for future generations and survival of the planet (Kauffman, 2009).

This study aimed to diagnose the main socio-ecological issues of Jardim Sant'ana neighborhood, city of Sousa, in the semiarid region of the state of Paraíba, and to assess the population's perception of environmental culture. Environmental perception research is of great importance because it can potentially determine the needs of a population and can propose improvements based on the understanding of problems and how to solve them in a more efficient manner (Palma, 2005). The results are discussed according to their potential for building strategies and paths for the foundation of public policies in the semiarid.

\title{
MATERIALS AND METHODS
}

\author{
Study area
}

This study was conducted in the neighborhood of Jardim Sant'ana, in the city of Sousa, state of Paraíba (PB). The city is located in the high semiarid area of the state and occupies an area of $842,275 \mathrm{~km}^{2}$. Sousa has 66,457 inhabitants, making it the sixth most populated city in the state.

The city polarizes seven counties of the $10^{\text {th }}$ Geoadministrative Region of Paraíba: Lastro, Marizópolis, 
Nazarezinho, Santa Cruz, São Francisco, São José da Lagoa Tapada and Vieirópolis. It is the main center in the northwest region of the state, with an average per capita income of 270.00 BRL (Brazilian Real). However, Sousa also registers per capita income values well below the state's capital João Pessoa (510.00 BRL). The city has a Municipal Human Development Index (MHDI) of 0.668, which is not overly low compared to that of João Pessoa (MHDI = 0.763). The Gini Index, which measures social inequality, is 0.49 (IBGE, 2010).

The neighborhood of Jardim Sant'ana is located on the periphery of the city and has approximately 3,000 inhabitants (5\% of the city's population), according to the family registry survey conducted by the Family Health Program (Programa de Saúde da Família - PSF). It should be noted that the neighborhood lacks urban infrastructure, with no schools, parks or health centers.

\section{Data collection}

This study follows a qualitative and quantitative approach, based on literature and documentary review, using field research, theoretical assumptions from phenomenological research and participant observation (Moreira, 2004). A proportion based on the number of houses on each street in the neighborhood was used to perform the interviews and to achieve an equal distribution on application. Between 3 and 10 interviews were performed on each street, based on the number of houses, totaling 80 oral interviews. A socio-ecological diagnosis was prepared with individuals of different ages, analyzing the environmental perception of the neighborhood residents. The interviewed group was composed of 30 men and 50 women, with 16 individuals in the 15- to 30-year age group, 48 individuals in the 31- to 60-year age group and 26 individuals in the more than 60-year age group. The interviews were conducted from January to March, 2014, at alternate times, with one adult from each family.

To investigate the environmental perception, the following factors were analyzed: environmental conceptions, socio-environmental issues of natural or anthropic origin that affect daily life, perception of these issues and the neighborhood's population knowledge sources. Prior to the interviews, each interviewee was informed of the objective of the study, and those who agreed to participate signed the Free and Informed Consent Form required by the National Health Council via the Ethics Research Committee (Resolution 196/96). This study was approved by the Ethics Committee for Human Research (Comitê de Ética em Pesquisa com Seres Humanos - CEP) of the Health Sciences Center of the Paraíba Federal University (Universidade Federal da Paraíba).

An awareness work was performed during each interview for data collection. At the end of the interview, based on the answers of the interviewees and after collecting all the necessary data, the researcher presented the most adequate concepts and feasible attitudes for the necessary changes in the population's environmental culture. This work aimed also at inducing an individualization of responsibilities toward the environment in which they live. Such vision is scarce, how can be evaluated during the research.

The identification and assessment of environmental impacts were performed according to the control listing method (Tommasi, 1994), in which the researcher gives each listed event a score from 1 to 5 , according to its importance. The consequences of these events are given scores from -5 to +5 , being -5 the value for the most intense negative impact, 0 (zero) if there is no impact and +5 for the most intense positive impact. The environmental impact index was then calculated (Equation 1). 
Equation 1

I IMPACT $=\sum(W E X C S)$

Where: I IMPACT = environmental impact index

$\mathrm{WE}=$ weight of events

$\mathrm{CS}=$ consequences score.

\section{RESULTS AND DISCUSSION}

\section{Environmental culture and perception: an analysis of the population of the Jardim Sant'ana neighborbood}

From 80 oral interviews performed with the population from 15 to 85 years of age, it was possible to detect some of the main characteristics of its environmental culture. Most of the neighborhood's population had lived there for over 10 years, as observed from the account of 75.6\% of the interviewees. Among them, $56.1 \%$ had lived there for over 20 years. Generally, the residents' habits were little concerned with sustainability.

A very clear socio-economic stratification was observed in the neighborhood, based on the house standards according to the areas/streets in the neighborhood, the variation in the employment of their owners and the schools that the children attended. Regarding the pleasantness of the neighborhood, the most mentioned aspect among the interviewees was "tranquility" (68.8\%). However, some of the interviewees, usually the youngest, stated that criminality has been affecting the neighborhood, with the occurrence of robberies in the area. It should be noted that "tranquility is not a perception, but a way of understanding the neighborhood as associated with wortby quality of life conditions" (Addison, 2003, p.81).

The neighborhood is bordered by the Diamante Dam to the right and Av. Pedro II to the left, one of the city's main streets. The houses located close to Diamante Dam are simpler and clearly more lacking in social structure. Closer to the limit of the neighborhood, on the opposite side of the dam, the houses become bigger and visibly more structured. The presence of social inequality is clear in the neighborhood, which is caused by the proximity to the water body, which is currently a problem for the population because of several impacts it has suffered and still suffers daily.

The Diamond Dam is the result of the barrage of the Rio do Peixe, a river that crosses the city of Sousa, to ensure water supply during drought periods. The Peixe river and the Piranhas river, forms the Peixe River Basin, which occupies an area of $1,424 \mathrm{~km}^{2}$ in an elongated elliptical shape in the WSE-WNW direction, divided into three sub-basins: the Brejo das Freiras or Triunfo, the Sousa and the Pombal. This basin contains important paleontological sites, showing evidence of dinosaur footprints and fossil deposits of fish and shellfish in the Sousa Formation, similar to those of the Araripe Basin (Rocha, 2006).

Similar to other cities, as the neighborhood of Jardim Sant'ana expanded, the Permanent Preservation Area of Diamante Dam was occupied, destroying its riparian forest and causing an accumulation of waste, and sedimenting the dam. Therefore, as a result of the lack of an area occupation policy, the streets closest to the dam suffer from constant floods, especially during the rainy periods. The dam is under constant earthing 
for the construction of houses and neighborhood growth, according to the residents themselves, who did not detect this action as an environmental issue of the area. Another important fact worth mentioning regarding the impact this aquifer suffers is the sewage from the neighborhood, which is sent to the aquifer without any type of treatment, indistinctly polluting one of the region's water bodies. In addition to material losses, the constant floods risk the lives and health of the people because the sewers are not treated and contaminate the water. Although the water resources are the responsibility of the Federal Union, the county plays an important role in maintaining and preserving water sources inside its territory; thus, it is very important that Sousa's county government monitors the dam's situation and proposes an improvement policy (Granziera, 2011).

The removal of vegetation protecting the margins of the dam causes the loss of plant species and exposes the soil to weather factors, such as rain and sun. Soil exposition to these climatic factors causes a reduction of its permeability, triggering serious problems such as erosion, degradation and impoverishment (Guerra et al., 2007). Vegetation coverage is essential for mitigating the impact of raindrops and decreasing the speed of superficial flow. In addition, vegetation coverage also serves as a protection, reducing the loss of soil by erosion (Frota; Nappo, 2012).

The present study suggests a cleaning and drainage project aimed at removing the waste accumulated inside the dam and its surroundings and renewing the dam's area so that, during the next flood, the neighborhood is not affected and the water source regains its drinking water quality. This effort needs to be integrated with treatment of the sewage that is deposited in the dam and a socio-environmental mobilization campaign with the surrounding population that can be extended to neighboring areas to avoid the return to the initial situation at the end of the city hall's action. According to the Federal Constitution, it is a consecrated right "the ecologically balanced environment, an asset for the common use of the people and vital to a bealthy quality of life, imposing on the Public Power and the society the duty to defend it and preserve it for the present and future generations" (Brazil, 1988) .

Several abandoned houses can be observed in the neighborhood. They close streets that should have exits, promoting social issues in the community. According to residents' reports, the families that lived in that area built the houses/sheds as a form of occupation, but those structures were abandoned after they received residences in other places from social programs. The old houses serve as shelter for criminals who walk the neighborhood's streets at night and cause fear in the population and also block the passage of waste collection vehicles on the streets, causing the irregular disposal of waste on the Diamante Dam. Despite the fact that the residents have mobilized and asked for solutions from the city hall, they have still not succeeded in their request for the removal of the houses.

Regarding the perception of what is environment and its conceptualization, it is easy to observe that only a small portion of the interviewees $(15.2 \%)$ know how to correctly conceptualize and reference what composes the environment, including other living beings, in their definition. The same percentage of interviewees $(15.2 \%)$ has an anthropocentric vision, declaring the environment as being only the "space where men live"; $27.8 \%$ associate it with "care for nature"; and 29.1\% declare not knowing how to conceptualize what the "environment" is (Figure 1).

Silva et al. (2006), while investigating rural families' perception of the Cariri of Paraíba, found that the majority of the interviewees $(91.66 \%)$ associated the environment with "a place to live", following a naturalist view. Villar et al. (2008), while studying of the northwest region of Rio de Janeiro population's environmental perception, also verified a naturalist view among $47.7 \%$ of the interviewees. The present study verifies a high 
index of people who are completely foreign to the environment in which they interact and who do not have the least conscious experience to be able to diagnose, even incompletely, the elements that make up the environment in which they are inserted. It is understandable that "the particularities of the term Environment can sometimes lead to a diffuse and variable conception, which brings an incomprehension of its true sense"; however, it is understood that by knowing how to characterize at least some portion of the elements that compose the environment, the individual becomes more sensible to conservation culture (Florentino, 2013, p. 71).

\section{Figure 1 - Perception about the term "Environment" from residents of a neighborhood in the Semiarid of Paraíba,} Northeast of Brazil.

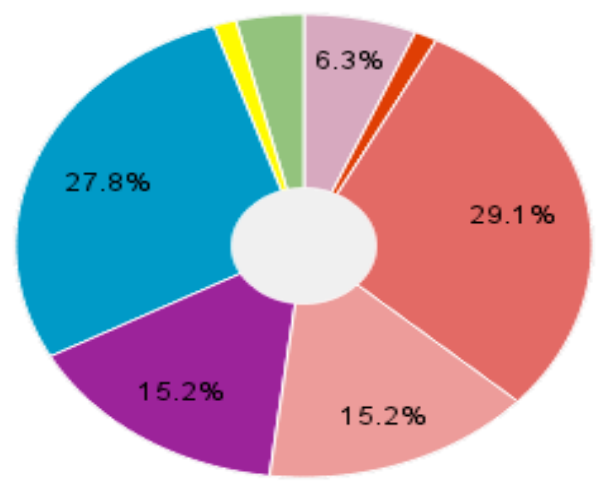

NATURE

VEGETATION

DOESN'T KNOW

THE SPACE WHERE MAN

LIVES

THE SPACE WHERE ALL LIVING BEINGS LIVE

- care for nature

CITIZENSHIP

CORRECT DISPOSAL OF

WASTE

Among those individuals who did not know how to conceptualize environment (29.1\%), all of them were older than 55, which indicates a narrower perception among elder adults. This result can be understood as a product of the lack of educational background and the lack of contact with a diversity of information vehicles. Older people were raised and lived with the perspective of those that colonized the Northeast's semiarid and understood that the environment was ugly, was inhospitable, lacked economic value, was unworthy and should be fought against, modified, and transformed to achieve another environmental reality (Santos, 2014). The perception of adults more than 56 years old who were analyzed in the present study is a reflection of the historical background of the population that currently inhabits the semiarid, which was based on the perspective of submission to the elite, domination of nature, and illiteracy. Among the interviewees in that age group, 10\% are illiterate and approximately $25 \%$ are functionally illiterate. Different from the present study, Miranda et al. (2007) observed that elderly groups in Belo Horizonte (MG) have, in general, a more naturalist perception of the environment in which they are inserted. That result can be related to a higher education level of the interviewees in Belo Horizonte and to the disparate social differences present in different regions of the country.

The younger respondents were more disconnected from their origins' history as a consequence of the cultural transformation process caused by the access to globalization and globalized lifestyle. Therefore, they are less bound by territory and the coexistence with the semiarid perspective but are more aware of the need to preserve the environment in general. Access to a formal education can also justify this higher knowledge compared to the elderly, who are mostly illiterate or have low educational backgrounds. Higher access to communication media brings cultural change (Silva, 2014). Interviewees from the 15- to 30-year-old age groups have more contact with various types of communication vehicles and higher levels of education. For example, in $90 \%$ of the houses, only those with ages of up to 35 years, used the Internet and other communication media besides the television and the radio.

It seems undeniable that the communication media play an important role as educative information 
multipliers. Several studies show that media, especially television, are responsible for most people receiving information on the environment (Luckman, 2006, p. 57).

Although the number of people who had an incorrect concept of environment was fairly high, when asked about the importance of the environment for their family's quality of life, $77 \%$ of the interviewees considered environmental balance highly important and considered that, to live well, the environment's conservation was greatly relevant (Figure 2). Despite the fact that $60 \%$ of the interviewees had some idea of what the environment is and that it is everyone's duty to preserve it, when asked about the Diamante Dam, they sometimes answered that it could be "removed" from the neighborhood because it causes several issues during river floods. There was a strong disconnection from the understanding of the natural resources closest to this population's experiences.

Figure 2 - The importance of the environment for the population of a neighborhood in the Semiarid of Paraíba, Northeast of Brazil.

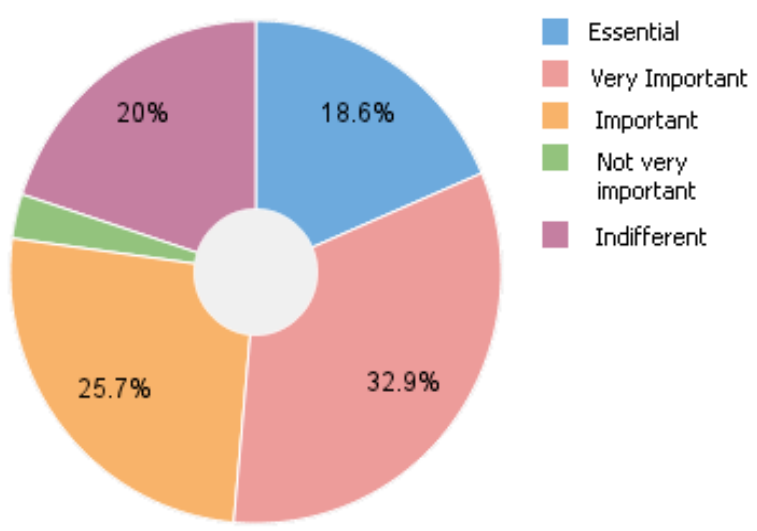

Some residents of the neighborhood were greatly concerned about cleanliness due to the local culture of constantly cleaning the house, the sidewalk and the street. However, the cleanliness speech is disconnected from the environmental experience because the respondents did not understand that, while they were removing waste from their sight, the residue produced was still present in the environment. They understand that it was both normal and their responsibility to have their waste sent to a dump site, even without separation or any type of waste treatment or reuse or even proper disposal. Habits such as washing sidewalks, irregular disposal of residues in the neighborhood's dam, not reusing water from clothes washing, and not gathering rain water were fairly common and were largely taught to the younger individuals. According to the perception of the interviewees, such attitudes are taken because there is a need to keep the environment clean. However, the interviewees seem to have a distorted vision of house cleanliness and an exaggerated appreciation of the private residential environment.

Despite this vision, the majority of the interviewees claim to separate organic and dry waste (74.4\%); however, this action is aimed at feeding the animals (50.6\%) or based on an understanding that they facilitate the work of garbage collectors, who constantly roam the streets of the neighborhood, retrieving garbage bags placed on the sidewalks. Moreover, when the dry waste is separated, the waste pickers do not need to "tear up the bags and soiling the streets", as stated by one of the interviewees, that did not associate the importance of separating the waste and the service that the waste pickers provide to the environment. From this percentage who claimed to separate the waste produced from their house, approximately $20 \%$ claimed this was not a common practice.

The city still does not have any type of selective collection or treatment of solid waste, despite the Solid 
Waste National Policy (Política Nacional dos Resíduos Sólidos - PNRS) (Law no. 12.305/2010) establishing that, by 2014, all Brazilian cities must have PNRS instruments implemented, particularly selective collection and integrated solid waste management (gerenciamento integrado de resíduos sólidos - GIRS) to eradicate dump sites (Brazil, 2010). However, Sousa is one of 50 cities from Paraíba that are interested in receiving the project "Construction of Socio-environmental Citizenship", developed by the Public Ministry of Paraíba (MPPB) to guide city halls regarding PNRS implementation. Unfortunately, Sousa's reality is not an isolated situation; by 2014 in Paraiba, few cities had managed to meet the goal set by the PNRS and have, in fact, started drafting the Management Plan for this new policy (MPPB, 2010).

Promoting a cultural change, such as the purpose of coexisting with the semiarid, is a very complex process that becomes even more difficult when the population in general does not have the least idea of what the environment they live in is. Another significant aspect that was clearly observed is the lack of understanding of the region and the biome in which the population lives, regardless of the age group. Most of the interviewees did not understand what Caatinga is and cannot conceptualize or list the characteristic elements of the biome (Figure 3). The lack of knowledge of the Caatinga biome was also noted in students of the Young and Adults Education program (Silva et al., 2012) and students of the Cariri of Paraíba (Abílio and Florentino, 2012). These results indicate that there must be a deficiency in understanding of the environment among the population of the semiarid of Paraíba.

Figure 3 - The understanding of the concept of "Caatinga" by the population of a neighborhood in the Semiarid of Paraíba, Northeast of Brazil.

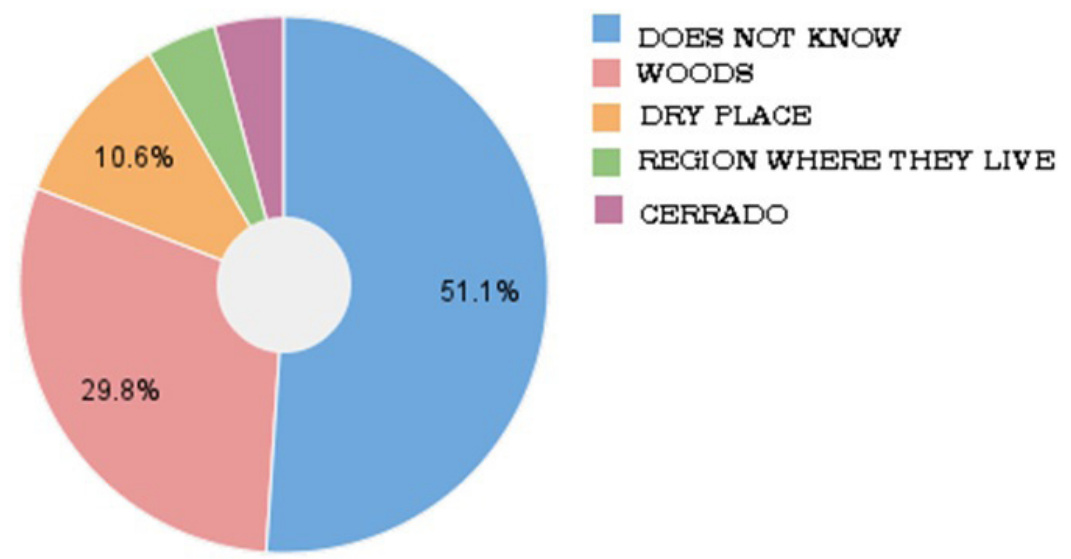

The neighborhood's population consists mainly of rural families that migrated to the city some decades ago. Many of them claim that when the occupation of the area started, they preserved their rural habits of hunting and cooking in wood burning stoves. However, only one of the interviewees still kept to this culture and cooked using charcoal. Among those who claim to hunt, they usually hunt eared dove (Z. auriculata ssp.), deer (Mazama spp.), quail (C. coturnix), ground dove (Columbina spp.), tegu (Tupinambis spp.), and opossum (Didelphis spp.). All the interviewees claim to hunt for sport, not for the need for food.

The City's Laundry Facility (Lavanderia Municipal), at the center of the neighborhood, is a place of violence and social insecurity because, according to the inhabitants, it houses criminals and drug users during the night, when there is no light and a decrease in foot traffic (10\% of the interviewees). The reflex of this feeling of insecurity that starts to permeate the residents' routine caused a high number of interviewees to note security 
as the neighborhood's main deficiency $(18.2 \%)$. When asked about the area's deficiencies, the most frequent answers aside from security were urban infrastructure (17.2\%), sewage (16.2\%), lack of public spaces for social interaction and leisure (15.2\%), and lack of a health center (15.2\%), as outlined in Figure 4.

\section{Figure 4 - The neighborhood's deficiencies, listed by percentage of the population of a neighborhood in the Semiarid of} Paraíba, Northeast of Brazil.

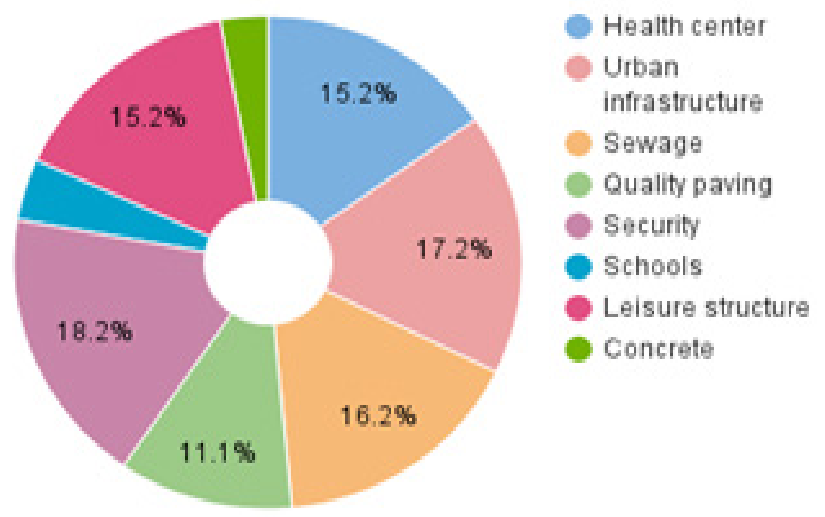

Water quality is among the serious problems of current society. Water is a carrier of several infectious diseases that can be transmitted by contact or direct ingestion of pathogenic bacteria and viruses present in contaminated water, by parasites that live in the water, or by vector insects that use the water as part of their life cycle, such as dengue fever (Petrovich; Araújo, 2009). Strict effort must be applied for the correct treatment of sewage and human wastes, which are two of the main causes for water quality degradation. Housing hygiene in the neighborhood is highly lacking in the poorest part of the city, mainly due to the pollution of Diamante Dam and its surroundings, which has been caused in part by the population that lives there. All the interviewees claimed to live with rats, mosquitoes and roaches; however, they did not make the connection between the presence of these animals and the pollution of the dam. Among the interviewees, $56 \%$ claimed that some of their families' residents had contracted dengue fever at least once.

This fact, together with the problems caused by the floods in the area, has changed the population's mind regarding the dam, which once supplied water for part of the city. In semiarid regions, dams usually represent not only a source of water but also a source of life and hope and have a broader meaning related to the settlement of men in the field (Petrovich; Araújo, 2009).

Environmental education (EE) has enabled the understanding and sensitization of society toward nature, aimed at minimizing socio-ecological issues, creating alternatives for improving quality of life and promoting sustainability, raising awareness about the environmental issues in the community (Guerra; Abílio, 2006). However, in the present study's population, there is a lack of any type of EE approach, not only because of the perceptions observed in the questionings described above but also because, when asked about what EE might be, approximately $60 \%$ of the interviewees did not know how to answer, claiming to have never heard the term. Once again, their disconnect with everything involved with the environment was made evident.

\section{Socio-ecological impacts on the Jardim Sant'ana neighborbood}

Based on the visits to the neighborhood for the diagnosis of socio-ecological impacts, it was listed 12 main impacts, all of them negative to the environment (Table 1). Eight of the twelve identified impacts received higher 
impact rates for being considered as having a high capacity of interference with the environment; therefore, the mean environmental impact index was -4.58 on a scale that ranged from -5 to +5 , with -5 indicating the most intense negative impact (Tommasi, 1994). This observation demonstrates the intensity of the environmental problems present in the studied neighborhood and the urgency for some actions that have to be provided to change this reality. Lopes et al. (2010), in a study carried out in the city of Assú, state of Rio Grande do Norte, using the same index to analyze the impact caused by dump sites, reported a mean environmental impact index of -4.25 .

Human activities cause changes in the physical, biotic and anthropic characteristics of the environment, which can be beneficial or adverse (Mota, 2010). The impacts observed in this ecosystem bring serious consequences to the environment, such as the possibility of extinction of animal and plant species, soil impoverishment, silting of rivers, lower rainfall index, etc. (Brasileiro, 2009; Carvalho, 2006). In the current scenario when we have the possibility of installation of a high-intensity social crisis that can be identified via the degradation of nature, climatic changes, extinction of species, deforestation, erosion, loss of quality of life, extreme poverty, gradual impoverishment and social exclusion, physical health (or the lack thereof), avoidable deaths, and other factors, it can be said that these and countless other facts are connected and affect each other mutually (Malvezzi, 2014).

Therefore, an environmental issue affects not only the natural resources but also men, their environment and their well-being, just as poverty also impacts the environment. An example of this relationship is the problem of precarious or absent basic sanitation and the lack of proper and sufficient collectors to accommodate waste, which cause human, social and environmental degradation. The use of firewood for cooking or selling and the occupation of risk areas should also be noted (Luzzi, 2012).

In the face of the identified impacts, the necessity of environmental sanitation in the neighborhood for achieving salubrity, environmental balance and life quality for the population becomes evident. "The implementation of an environmental sanitation program in an area requires its proponents to develop a systematic vision of the theme and to find multiple, but integrated, solutions to the presented problems" (Senra et al. 2012, p. 56).

The necessity of incisive work with the population aimed at causing local environmental culture changes is also clear, as there is a close relationship between the environment and the population that lives in it, and changes in one of these factors are only effective when the other is simultaneously changed. In regard to the analyzed case, both the environment and the population require changes, as the environment is much degraded, and the population is highly oblivious to the perception of the environment in which they live.

The population identifies with only four of different impacts surveyed in this study (irregular disposal of residues, wasting of water, lack of basic sanitation, pollution of watercourses); however, they did not demonstrate an understanding that such impacts are caused by the neighborhood's population itself. The population places the entire fault on the government, exempting themselves as causes of the situation, taking the victims' position. They claim that the population discards the garbage in the dam and justify this action as due to the lack of collection in some of the neighborhood's dead-end streets. They admit that sewage collection is sent to the dam without treatment. Regarding wasting water, they exhibit economic attitudes but, due to the drought they face, do not understand that they use more water than what they need or could use. 
Table 1 - List of impacts surveyed and local aspects from a neighborhood in the Semiarid of Paraíba, Northeast of Brazil.

\begin{tabular}{|c|c|c|c|c|}
\hline Impacts & Neighborhood's aspects & Weight & Score & $\begin{array}{l}\text { Weight } x \\
\text { Score }\end{array}$ \\
\hline $\begin{array}{l}\text { Mischaracterization of } \\
\text { the biome Caatinga }\end{array}$ & $\begin{array}{l}\text { The neighborhoods' trees are exotic } \\
\text { species }\end{array}$ & 5 & -5 & -25 \\
\hline $\begin{array}{l}\text { Absence of green } \\
\text { areas }\end{array}$ & $\begin{array}{l}\text { There are no parks, preserved areas, } \\
\text { flower beds, etc. }\end{array}$ & 5 & -5 & -25 \\
\hline $\begin{array}{l}\text { Felling of riparian } \\
\text { forest }\end{array}$ & $\begin{array}{l}\text { Vegetation on the margin of } \\
\text { Diamante Dam has been explored } \\
\text { and replaced by houses }\end{array}$ & 5 & -4 & -20 \\
\hline Construction on PPA & $\begin{array}{l}\text { Many of the area's houses are built } \\
\text { within the limits of the Diamante } \\
\text { Dam PPA }\end{array}$ & 5 & -5 & -25 \\
\hline Soil pollution & $\begin{array}{l}\text { Waste and sewage are directed to } \\
\text { Diamante Dam and in the open }\end{array}$ & 5 & -5 & -25 \\
\hline $\begin{array}{l}\text { Irregular } \\
\text { disposal }\end{array}$ & $\begin{array}{l}\text { Garbage from many houses is } \\
\text { thrown into Diamante Dam or } \\
\text { abandoned lots }\end{array}$ & 5 & -5 & -25 \\
\hline Soil waterproofing & $\begin{array}{l}\text { The entire neighborhood is paved, } \\
\text { and the population fights to have } \\
\text { concrete despite it being an area of } \\
\text { high occurrence of floods at the } \\
\text { margin of the Peixe River. }\end{array}$ & 5 & -4 & -20 \\
\hline Water waste & $\begin{array}{l}\text { The population washes the sidewalks } \\
\text { daily } \\
\text { Constant leakages are present on the } \\
\text { streets }\end{array}$ & 5 & -5 & -25 \\
\hline $\begin{array}{l}\text { Lack of basic } \\
\text { sanitation }\end{array}$ & $\begin{array}{l}\text { Part of the population lives in risk } \\
\text { areas that completely lack sanitary, } \\
\text { social and habitation conditions }\end{array}$ & 5 & -5 & -25 \\
\hline $\begin{array}{l}\text { Pollution } \\
\text { watercourses }\end{array}$ & $\begin{array}{l}\text { Waste and sewage are directed to } \\
\text { Diamante Dam }\end{array}$ & 5 & -5 & -25 \\
\hline $\begin{array}{l}\text { Contamination and } \\
\text { pollution of the air }\end{array}$ & $\begin{array}{l}\text { Odor is present in areas close to the } \\
\text { dam } \\
\text { Gases are produced from the } \\
\text { irregular disposal of waste }\end{array}$ & 4 & -4 & -16 \\
\hline Visual pollution & $\begin{array}{l}\text { The green area at the limits of the } \\
\text { neighborhood looks like a dump site } \\
\text { area }\end{array}$ & 3 & -3 & -9 \\
\hline Total / Average & & 57 & -4.58 & -265 \\
\hline
\end{tabular}


Quality of life and urban public policies to coexist with the semiarid

A healthy quality of life is a basic element for the Brazilian Federal Constitution, as outlined in article 225, caput, intrinsic to human survival; thus, a healthy quality of life is an imperative and inalienable fundamental human right, inseparable from the right to life (Brazil, 1988). This established right cannot be considered other than in conjunction with social, economic, political, cultural and environmental factors in a process where there is intra- and inter-management responsibility. The necessity of enabling a befitting management of environmental resources compatible with the full sustainable satisfaction of fundamental human desires is urgent (Oliveira et al., 2011).

Human survival cannot be considered dignified or in proper physical or psychological conditions when the environment in which the individual is inserted is unhealthy, contaminated, altered or degraded in a way that affects its well-being and its coexistence and quality of life. Much has been accomplished to improve the quality of life of the inhabitants of the rural area of the semiarid, and powerful initiatives are increasingly being replicated and gaining strength to connect the populations of the Northeast's semiarid in a network. The main examples are the incentive of projects directed toward solidary economy and the empowerment of women and the construction of cisterns to gather water (Malvezzi, 2014); however, it is not possible to analyze the Brazilian semiarid based only on the rural region, where the population there is in a situation of greater vulnerability. The urban issue has become as fundamental as the rural issue. The paradigm of coexistence with the semiarid will also need to include the urban area. Therefore, the coexistence with the semiarid becomes the focus of a more systemic and integrated survey of the region, articulating rural and urban realities based on the same cause (Malvezzi, 2014).

In the current scenario, most of the semiarid region population already lives in cities, but it is still the most rural of the country's regions. According to Malvezzi (2014, p.104), "the population of the semiarid region is estimated at approximately 22 million people, with 38\% (approximately 8.5 million) living in the rural area". The society that lives in the semiarid is still represented by politicians that adopt client-oriented practices inherited from the political paradigm that was common during the 80 s and that has been, since even before then, highly ineffective and antidemocratic. The life and survival of programs are dated by electoral mandate periods of the representatives, as was done decades ago (Cohn, 1995). The political reality and social problems have propagated throughout the years due to a lack of interest in changing. According to Baptista et al. (2014b, p. 84), "the ownership of the land and the use of water remain concentrated, and there is a high number of migrants of the same region working in conditions similar to slavery in the lands of landowners".

It is increasingly urgent that policies directed toward urban populations be developed in the semiarid of Paraíba, as this study clearly shows the disconnection between the population that lives in Sousa and the environmental culture that the region requires. The rural population, throughout the years, has developed ways of coexisting with the adverse conditions that the area imposes. However, the lifestyle imposed on the urban population, in which not even the greatest problem of the region - water scarcity - was treated rationally, became responsible for this disconnection between the city and the environment it inhabits. The massive constructions planned to provide water and to guarantee an abundance to those that live in urban areas are cause for such distancing.

The population's life quality shall become a priority to public administrators to guarantee the perpetuation 
of the culture that enabled the population to maintain a good coexistence with the semiarid. Thus, it is highly important that there be a political mobilization toward the elaboration of public policies that achieve the transformation of the population's environmental culture and socio-environmental reality, allowing a better experience and ensuring the non-degradation of the region, moving opposite to the current reality, as presented above.

\section{CoNCLUSION}

The Jardim Sant'ana neighborhood's population do not know basic concepts of environment organization and how their action can impact it. The environmental impact index indicates the intensity of the existing environmental problems and the urgent need of changes in the socio-ecological reality of the studied neighborhood, with the proposal of environmental sanitation actions and improvements in the environmental perception of the population.

The semiarid urban population needs an urgent cultural change regarding coexistence with the semiarid from an Environmental Education perspective. The proposal of continuous, as opposed to specific, policies for the population to assimilate via awareness emphasizes the vision that the human being is a transformer element of its environment and is one of the main elements capable of both causing socio-ecological problems and promoting life quality to the population of the semiarid.

\section{REFERÊNCIAS}

Abílio FJP e Florentino HS 2012. Educação Ambiental no Bioma Caatinga: o que Pensam os Alunos do I Curso de Especialização em Educação Ambiental para o Semiárido [Environmental Education in the Biome Caatinga: What do the Students of the I Specialization in Environmental Education Course Think about the Semiarid]. In: Abílio, F.J.P. Educação Ambiental: da prática educativa à formação continuada de professores do semiárido paraibano. João Pessoa: UFPB/ Ed. Universitária.

Abílio FJP. e Sato M. (Org.). 2012. Educação Ambiental: do currículo da educação básica às experiências educativas no contexto do semiárido paraibano [Environmental Education: from basic education curriculum to education experiences in the context of the semiarid of Paraíbaç]. João Pessoa: UFPB/ Ed. Universitária.

Addison EE. 2003. A percepção ambiental da população do município de Florianópolis em relação à cidade [The environmental perception of the population of the city of Florianópolis regarding the city]. Florianópolis. Available at: http://repositorio.ufsc.br/handle/123456789/86146>. Accessed on: jan 2015.

Albuquerque UP et al. 2010. Caatinga: biodiversidade e qualidade de vida [Caatinga: biodiversity and quality of life]. Bauru,SP: Canal 6. Available at:<http://migre.me/oyQ1T>. Accessed on: Dec 9, 2014.

Baptista NQ, Campos CHA. 2014a. A convivência com o semiárido e suas potencialidades [Coexistence with the semiarid and its potentials]. In: Conti IL et al (Org.). Construindo saberes, cisternas e cidadanias: formação para a convivência com o semiárido brasileiro. Editora IABS, Brasília, DF. 
2014b. Acesso à terra e à água - direitos, liberdade e cidadania no Semiárido [Access to land and water - rights, liberty and citizenship in the Semiarid]. In: Conti, I. L. et al (Org.). Construindo saberes, cisternas e cidadanias: formação para a convivência com o semiárido brasileiro. Editora IABS, Brasília, DF.

2013. Caracterização do semiárido brasileiro [Characterization of the Brazilian semiarid]. In: Conti, I. L. et al (Org.). Convivência com o semiárido brasileiro: autonomia e protagonismo social. Editora IABS, Brasília, DF.

Bauman Z. 2007. Vida líquida [Liquid life]. Rio de janeiro: Jorge Zahar Ed.

Branco SM. 2004. O meio ambiente em debate [Environment under debate]. 3 ed. rev. e ampl. - São Paulo: Moderna (Coleção Polêmica).

Brasil. Constituição (1988) [Constitution]. Constituição da República Federativa do Brasil: promulgada em 5 de outubro de 1988. Available at:<http://www.planalto.gov.br/ccivil_03/Constituicao/ConstituicaoCompilado. htm>. Accessed on: mar 2015.

Brasil. Constituição da República Federativa do Brasil de 1988 [Constitution of the Federative Republic of Brazil, 1988]. Brasília, 1988. Available at:<http://www.planalto.gov.br/ccivil_03/Constituicao/Constituicao. htm>. Accessed on: mar 2015.

Lei n ${ }^{\circ}$ 12.305 - Política Nacional de Resíduos Sólidos [Law no. 12.305 - National Policy of Solid Residues]. Brasília, 2010. Available at: <http://migre.me/oyPQB> Acesso em: jan 2015.

Brasileiro RS. 2009. Alternativas de desenvolvimento sustentável no semiárido nordestino: da degradação à conservação [Alternatives to sustainable development in the northeast's semiarid: from degradation to conservation]. Available at: < http://migre.me/oyPZz>. Accessed on: jan 2015.

Carvalho LD. 2006. A emergência da lógica da "Convivência Com o Semi-Árido" e a construção de uma nova territorialidade [Emergence of logic of "Coexistence with the Semiarid" and the construction of a new territoriality]. In: Educação para a Convivência com o Semi-Árido Árido: Reflexões Teórico-Práticas. Juazeiro/BA: Secretaria Executiva da Rede de Educação do Semi-Árido, Selo Editorial-RESAB.

Carvalho RVA. 1987. Coronelismo e neo-coronelismo: eternização do quadro de análise política no Nordeste? ["Coronelismo" and "neo-coronelismo": externalization of political analysis situation in the Northeast?]. Caderno de Estudos Sociais. v. 3, n. 2. Available at: $<$ http://periodicos.fundaj.gov.br/CAD/ article/view/1025>. Accessed on: mar 2015.

Cohn A. 1995. Políticas Sociais e Pobreza no Brasil [Social Policies and Poverty in Brazil]. Planejamento e Políticas Públicas. N.12, Jun/Dec.

Crispim MC. 2008. Ecologia [Ecology]. In: Andrade, M. O. (Org.). Meio Ambiente e Desenvolvimento. Bases para uma formação interdisciplinar. João Pessoa: Editora Universitária da UFPB.

Florentino HS. 2013. Educação ambiental no Bioma Caatinga: por uma formação continuada de professores no município de Sumé-PB [Environmental education in the Biome Caatinga: for a 
continuous formation of professors in the city of Sumé-PB]. PRODEMA. João Pessoa.

Frota PV, Nappo ME. 2012. Processo erosivo e a retirada da vegetação na bacia hidrográfica do açude Orós - CE [Erosion process and removal of vegetation in the hydrographic basin of Orós dam - CE]. Revista Geonorte, Edição Especial, v. 4, n. 4, p.1472 - 1481.

Granziera MLM. 2011. Áreas de preservação permanente urbanas, drenagem e compensação ambiental [Urban permanent preservation areas, drainage and environmental compensation]. In: Benjamin $\mathrm{AH}$ et al. (coords.). PNMA: 30 anos da Política Nacional de Meio Ambiente. São Paulo: Imprensa Oficial do Estado de São Paulo.

Guerra AJT, Silva SS, Botelho RGM. 2007. Erosão e conservação dos solos [Erosion and conservation of soils]. Editora Bertrand Brasil, $3^{\circ}$ edição.

Guerra RAT, Abílio FJP. 2006. Educação Ambiental na Escola Pública [Environmental Education at the Public School]. João Pessoa: Foxgraf.

Kauffman C. 2009. Estudos culturais, mídia e meio ambiente: Tecendo saberes para uma cultura ambiental [Cultural studies, media and environment: Weaving knowledge for an environmental culture]. Quinto Encontro de Estudos Multidisciplinares em Cultura.

Lopes et al. 2010. Avaliação dos impactos ambientais causador por lixões: um estudo de caso [Evaluation of environmental impacts caused by dump sites: a case study]. Anais do XXVII Congresso Interamericano de Engenharia Sanitária e Ambiental. ABES - Associação Brasileira de Engenharia Sanitária e Ambiental.

Luckman AP. 2006. Jornalismo e mídia-educação no contexto do aquecimento global [Journalism and media education in the context of global warming]. Estudos em Jornalismo e Mídia. Vol. III No 2.

Luzzi D. 2012. Educação e Meio Ambiente [Education and Environment]. Barueri,SP: Manole.

Malvezzi R. 2014. O desafio das cidades no semiárido brasileiro [The challenge of cities in the Brazilian semiarid]. In: Conti, I. L. et al (Org.). Construindo saberes, cisternas e cidadanias: formação para a convivência com o semiárido brasileiro. Editora IABS, Brasília, DF.

Martins et al. 2011. Coronelismo: um referente anacrônico no espaço organizacional brasileiro contemporâneo? [“Coronelismo": an anachronistic reference in contemporary Brazilian organizational space?]. Rev. O\&E - Salvador, v.18 - n.58, p. 389-402. Available at: <http://www.scielo.br/pdf/osoc/v18n58/ a03v18n58.pdf>. Accessed on fev 2015.

Miranda et. al. 2007. Representações Sociais Sobre Educação Ambiental em Grupos da Terceira Idade [Social Representations about Environmental Education in Elderly Groups]. Available at: < http://www. scielo.br/pdf/ciedu/v13n1/v13n1a02.pdf.>. Accessed on: jan 2015.

Mitidiero Junior MA. 2008. Ação territorial de uma igreja radical: Teologia da libertação, luta pela terra e atuação da Comissão Pastoral da terra no Estado da Paraiba. São Paulo. Available at: <http://www.teses. usp.br/teses/disponiveis/8/8136/tde-07012009-161303/pt-br.php>. Acessed on: mai 2017. 
Moreira DA. 2004. O Método Fenomenológico na Pesquisa [Phenomenological Method in Research]. São Paulo: Pioneira Thomson Learnig, 152p.

Mota S. 2010. Introdução à engenharia ambiental [Introduction to environmental engineering]. $4^{\mathrm{a}}$ Edição. Rio de Janeiro. ABES: Associação Brasileira de Engenharia Sanitária e Ambiental.

MPPB. 2010. Planejamento Estratégico 2010/2016 [Strategic Planning 2010/2016]. Available at:<http:// migre.me/oyPKm>. Accessed on: jan 2015.

Oliveira KA., et al. 2011. Qualidade de vida, alimento e ambiente: análise socioambiental e jurídica fundamental [Quality of life, food and environment: fundamental socio-ecological and legal analysis]. In: Benjamin, A. H. et al. (coords.). PNMA: 30 anos da Política Nacional de Meio Ambiente. São Paulo: Imprensa Oficial do Estado de São Paulo.

Palma IR. 2005. Análise da percepção ambiental como instrumento ao planejamento da educação ambiental [Environmental perception analysis as an instrument for planning of environmental education]. UFRS. Available at:< http://migre.me/oyPGu>. Accessed on: jan 2015.

Petrovich AI, Araújo MFF. 2009. Percepção de professores e alunos sobre os usos e a qualidade da água em uma região semi-árida brasileira [Teachers and students' perceptions about uses and quality of water in a semiarid region of Brazil]. Revista Educação Ambiental em Ação. No 29. Available at:<http:// migre.me/oyQd7>. Accessed on: jan 2015.

Rocha D, et al. 2006. Geologia da Bacia do Rio do Peixe [Geology of the Rio do Peixe Basin]. Rede Cooperativa de Pesquisa Comportamento das Bacias Sedimentares da Região Semi-Árida do Nordeste Brasileiro. Hidrogeologia da Bacia do Rio do Peixe. Available at:<http://migre.me/oyPEa>. Accessed on: jan 2015.

Santos CF. 2014. Terra: base para a convivência com o Semiárido brasileiro [Earth: base for coexistence with the Brazilian semiarid]. In: Conti, I. L. et al (Org.). Construindo saberes, cisternas e cidadanias: formação para a convivência com o semiárido brasileiro. Editora IABS, Brasília, DF.

Salles A. 2012. Do coronelismo ao neo-coronelismo: um estudo sobre a ascensão, a queda e o ressurgimento de Antônio Lorenzetti Filho [From "coronelismo" to "neo-coronelismo": a study on the rise, fall and rebirth of Antônio Lorenzetti Filho]. 100 f. Dissertação (mestrado) - Universidade Estadual Paulista, Faculdade de Ciências e Letras de Araraquara, 2012.

Senra JB, et al. (Org.). 2012. Ciranda das Águas [Water Cycle]. Ministério do Meio Ambiente. Available at:

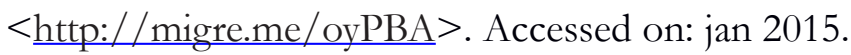

Silva EDC. 2014. Mudanças Culturais [Cultural Changes]. In: Conti IL, et al (Org.). Construindo saberes, cisternas e cidadanias: formação para a convivência com o semiárido brasileiro. Editora IABS, Brasília, DF.

Silva MA, et al. 2012. Educação Ambiental na Educação de Jovens e Adultos no Semiárido Paraibano [Environmental Education in the Education of Youth and Adults in the Semiarid of Paraíba]. In: ABÍLIO, 
F.J.P.; Sato, M. (Org.) Educação Ambiental: do currículo da educação básica às experiências educativas no contexto do semiárido paraibano. João Pessoa: UFPB/ Ed. Universitária.

Silva MMP et al. 2006. Educação Ambiental para o uso sustentável de água de cisternas em comunidades rurais da Paraíba [Environmental Education for the sustainable use of cistern water in rural communities of Paraíba]. Revista de Biologia e Ciências da Terra. Suplemento Especial - Número 1 - $2^{\circ}$ Semestre. Available at:<http://migre.me/oyQ7T>. Accessed on: fev 2015.

Totet L. 2014. A violência, a corrupção e a fraude eleitoral: herança coronelista a ser corrigida por uma reforma política [Violence, corruption and electoral fraud: heritage from "coronelismo" to be corrected by a political reform]. 147 f. Dissertação (mestrado) - Universidade de Fortaleza.

Tommasi LR.. 1994. Estudos de Impacto Ambiental [Environmental Impact Studies]. CETESB: Terragraph Artes e Informática. São Paulo.

Villar LM, et al. 2008. A percepção ambiental entre os habitantes da região noroeste do estado do Rio de Janeiro [Environmental perception among inhabitants of the northeast region of the state of Rio de Janeiro]. Esc. Anna Nery Rev. Enferm. Pág. 537-43. Available at: <http://www.scielo.br/pdf/ean/v12n3/ v12n3a21>. Accessed on: fev 2015. 